\title{
Effects of Mississippi River water on phytoplankton growth and composition in the upper Barataria estuary, Louisiana
}

\author{
Ling Ren $\cdot$ Nancy N. Rabalais $\mathbb{D} \cdot$ R. Eugene Turner
}

Received: 14 August 2019/Revised: 11 January 2020/Accepted: 21 February 2020/Published online: 3 March 2020

(C) The Author(s) 2020

\begin{abstract}
Diversion of river waters to adjacent estuaries may occur during wetland restoration, navigation channel development, or storms. We proposed that diversions of nitrogen- and phosphorus-enriched waters from the river to estuarine waters would result in increased phytoplankton biomass and shifts to noxious or harmful algal blooms. We tested this hypothesis by conducting four seasonal microcosm experiments in which Mississippi River water was mixed at different volume ratios with ambient
\end{abstract}

Handling editor: Jonne Kotta

Electronic supplementary material The online version of this article (https://doi.org/10.1007/s10750-020-04214-0) contains supplementary material, which is available to authorized users.

\section{Present Address:}

L. Ren

Department of Environmental Science and Policy,

College of Science, George Mason University, Fairfax,

VA 22030, USA

e-mail: lren2@gmu.edu

L. Ren

The Academy of Natural Sciences of Drexel University, Philadelphia, PA 19103, USA

N. N. Rabalais $(\bowtie) \cdot$ R. E. Turner

Department of Oceanography and Coastal Sciences,

College of the Coast and Environment, 3161 Energy,

Coast and Environment Building, Louisiana State

University, Baton Rouge, LA 70803, USA

e-mail:nrabal@1su.edu estuarine waters of three lakes in the upper Barataria Basin, Louisiana, USA. These lakes included two brackish lakes that were in the path of diverted Mississippi River water, and a freshwater lake that was not. The results from the 3- to 8-day experiments yielded a predictable increase in phytoplankton biomass related to nutrient additions from Mississippi River water. The subsequent decreases in the dissolved nitrate + nitrite, soluble reactive phosphorus, and silicate concentrations explained 76 to $86 \%$ of the increase in chlorophyll $a$ concentrations in the microcosms. Our experiments showed that cyanobacteria can successfully compete with diatoms for $\mathrm{N}$ and $\mathrm{P}$ resources even under non-limiting $\mathrm{Si}$ conditions and that toxic cyanobacteria densities can increase to bloom levels with increased Mississippi River water

\author{
R. E. Turner \\ e-mail: euturne@1su.edu
}


inputs to ambient waters in the microcosms. Diversions of Mississippi River into adjacent estuarine waters should be considered in relation to expected and, possibly, unexpected changes in phytoplankton communities to the receiving waters and coastal ecosystems.

Keywords Mississippi River diversions - Nutrient enrichment · Phytoplankton community · Toxic algae Eutrophication

\section{Introduction}

Eutrophication is symptomatic of estuaries with relatively long water residence times and nutrient enrichment (Rabalais, 2004). The increased carbon production is often accompanied by a changing phytoplankton community composition that commonly leads to the appearance and blooms of noxious or toxic harmful algae and oxygen-depleted waters (Dortch et al., 1999; Rabalais, 2004). High phytoplankton biomass is well documented in the Barataria Bay estuary bordering the western levee of the Mississippi River (Turner et al., 2019). Similar conditions exist in estuaries east of the Mississippi River during high flow conditions and when river water is diverted into Lake Pontchartrain and other estuaries (Dortch et al., 1999; Turner et al., 2004; Ren et al., 2009; Riekenberg et al., 2015; Bargu et al., 2019). Understanding the dynamic relationships between nutrient enrichment and phytoplankton growth is an important goal to accurately predict, manage, and, perhaps, reverse eutrophication.

Assessing and predicting the consequences of eutrophication can be complicated by the various nutrient quantities and their ratios, the timing of the nutrient loadings, and the complex suite of other environmental factors and trophic interactions in receiving basins (Glibert et al., 2010). The nutrient(s) limiting phytoplankton growth in estuarine and coastal waters, for example, may include $\mathrm{N}, \mathrm{P}$, or $\mathrm{Si}$ limitation, as well as co-limitation (Turner et al., 1990; Sylvan et al., 2006; Ren et al., 2009; Turner \& Rabalais, 2013; Paerl et al., 2016). Furthermore, although there are strong correlations between the concentration of chlorophyll $a(\mathrm{Chl} a)$ and both total nitrogen (TN) and/or total phosphorus (TP) in estuaries and coastal waters (Guildford \& Hecky, 2000; Hoyer et al., 2002; Nielsen et al., 2002; Smith, 2006; Cloern et al., 2016), caution is needed to define these relationships. The TN and TP in phytoplankton$\mathrm{N}$ and -P, for example, may not be the dominant component of TN and TP in the water column. Even when phytoplankton biomass is subtracted from TN and TP, as in some studies (e.g., Nielsen et al., 2002), microzooplankton may graze substantial amounts of the phytoplankton biomass resulting from nutrient enrichment (Murrell et al., 2002; Wong et al., 2016). Thus, the internal biological interactions and nutrient regeneration vary in different aquatic systems and, consequently, their responses to external nutrient inputs may differ.

The estuarine waters adjacent to the lower Mississippi River are subject to numerous nutrient inputs via natural processes, from human-influenced high nutrient loads, and from human-engineered movement of Mississippi River water through river diversions and siphons. The Davis Pond Diversion (DPD), completed in 1992, and located $190 \mathrm{~km}$ above the Mississippi River delta, diverts river water into the upper Barataria Basin (Fig. 1). Moving Mississippi River water into the estuary could aggravate the eutrophication problems in the estuaries, which are already eutrophic to hypereutrophic (Turner et al., 2019). The construction and operation of the DPD was planned to bring fresh water into the upper Barataria Basin (CPRA, 2017). Other diversions are designed to bring more sediment into the Barataria Basin. There will always be much higher nutrient concentrations when either fresh water or sediments from the Mississippi River enter estuarine waters. We know from marsh fertilization experiments that additional $\mathrm{N}$ and $\mathrm{P}$ leads to marsh loss (Turner, 2011; Deegan et al., 2012) and that additional nutrients to lake microcosms enhanced chlorophyll biomass accumulation and can potentially promote harmful algal blooms (Ren et al., 2009).

Here we report the results from controlled experiments in microcosms (3-7 days) that document the responses of phytoplankton to the addition of mostly nutrient-rich Mississippi River water into the estuarine waters of Barataria Bay. We previously completed a series of nutrient addition experiments to determine qualitatively nutrient limitation on phytoplankton growth in the same lakes (Ren et al., 2009). We discuss here the quantitative effects of River water as a whole and on a seasonal basis as nutrient 


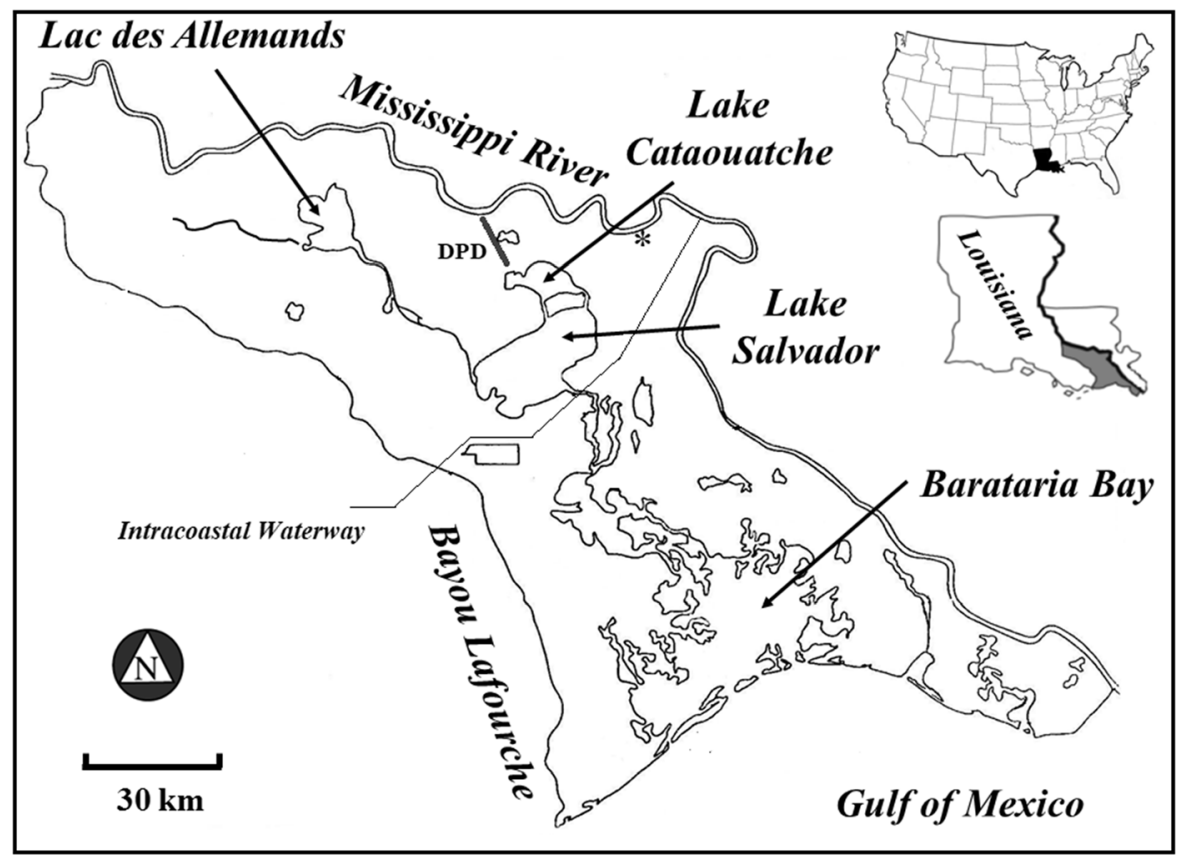

Fig. 1 Map of the study area in the Barataria Bay estuary, Louisiana, identifying the three lakes of concern and location of the Davis Pond Diversion (DPD). The asterisk (*) identifies the location of Mississippi River water collections

concentrations in ambient waters change their concentration and ratios. We hypothesized that the increased River water nutrient loading into three lakes (fresh water to brackish salinities) would increase the growth of phytoplankton and cause a shift in phytoplankton species composition.

\section{Materials and methods}

Study area

The Barataria Basin estuary is located in Louisiana's Mississippi River Deltaic Plain. The western margin is bordered by Bayou Lafourche, and the eastern margin is the west bank of the Mississippi River (Fig. 1). The three lakes (average depth 1 to $2 \mathrm{~m}$ ) are in the upper Barataria Basin and receive nutrient runoff from the surrounding urban and agricultural areas. Lac des Allemands and Lake Cataouatche are freshwater lakes and Lake Salvador is somewhat saltier, but less than 5 psu (see below). A narrow channel connects lakes Cataouatche and Salvador. The water volume of lakes Cataouatche and Salvador is estimated to be about $7.46 \times 10^{7} \mathrm{~m}^{3}$ and $3.96 \times 10^{8} \mathrm{~m}^{3}$, respectively. The
Chl $a$ concentration in Lac des Allemands from 1994 to 2016 varied between 20 to more than $100 \mu \mathrm{g} \mathrm{l^{-1 }}$, identifying it as hypereutrophic, with seasonally dense cyanobacterial blooms (Turner et al., 2019). Lake Cataouatche is moderately eutrophic (average Chla of 9 to $30 \mu \mathrm{g} \mathrm{l}^{-1}$ ), whereas Lake Salvador to the south is the least eutrophic (average Chla of 6 to $14 \mu \mathrm{g} \mathrm{l}^{-1}$ ) among the three lakes (Ren et al., 2009; Turner et al., 2019).

The DPD opened in 2002 and diverted Mississippi River water into Lake Cataouatche, where water flowed into Lake Salvador, and then downstream into the lower Barataria Basin (Fig. 1). Three river diversions occurred during the experiments (Fig. 2). These diversions delivered a daily discharge averaging 1 to $3 \times 10^{6} \mathrm{~m}^{3} \mathrm{~d}^{-1}$. The high discharge in JanuaryMarch 2006 was $1 \times 10^{8} \mathrm{~m}^{3} \mathrm{~d}^{-1}$, which could replace $14 \%$ of the water in Lake Cataouatche every day, and $2.5 \%$ per day for Lake Salvador (Table 1).

\section{Experimental design}

Four sets of microcosm experiments were conducted seasonally on lakes Cataouatche and Salvador and Lac des Allemands from May 2005 to February 2006. Lake 


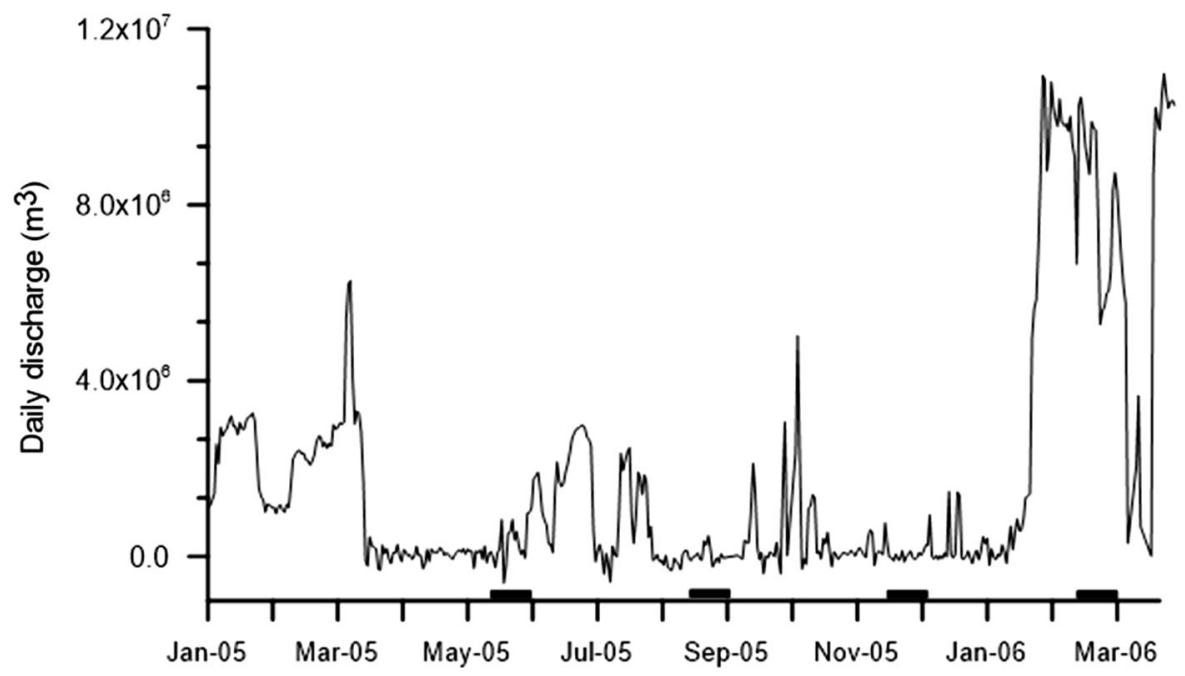

Fig. 2 Davis Pond Diversion (DPD) daily discharge $\left(\mathrm{m}^{3} \mathrm{~d}^{-1}\right)$ at the time of four experiments (indicated with horizontal bars). The time of four sets of experiments: May 16-26, August 15-26, November 28-December 14 of 2005, and February 13-March 1 of 2006

Table 1 Estimate of lake water replacement by DPD discharge per day at the time of four experiments

\begin{tabular}{lllcc}
\hline Lake & Experiment & Experiment duration & DPD discharge $\left(\times 1000 \mathrm{~m}^{3}\right)$ & Water replacement (per day) $(\%)$ \\
\hline Cataouatche & May05 & May 23-26, 2005 & $370-845$ & $0.5-1.1$ \\
& Aug05 & Aug. 15-18, 2005 & $0-18$ & $0-0.02$ \\
& Nov05 & Nov. 28-Dec. 4, 2005 & $0-258$ & $0-0.35$ \\
Salvador & Feb06 & Feb. 13-20, 2006 & $6648-1044$ & $9-14$ \\
& May05 & May 16-19, 2005 & $0-842$ & $0-0.21$ \\
& Aug05 & Aug. 15-18, 2005 & $0-18$ & $0-0.004$ \\
& Nov05 & Nov. 28-Dec. 4, 2005 & $0-258$ & $0-0.07$ \\
\hline
\end{tabular}

water was collected from the middle of each lake. Mississippi River water was collected from the Louisiana Universities Marine Consortium (LUMCON) Audubon Zoo monitoring station (29 55.260' $\mathrm{N}, 90^{\circ} 8.070^{\prime} \mathrm{W}$ ) in New Orleans (Fig. 1). An additional 1-1 water sample was taken from each station to measure the initial water conditions in the River and lakes. The samples were transported to the LUMCON Marine Center in Cocodrie, Louisiana, within $3 \mathrm{~h}$ of collection. The Mississippi River water (RW) was mixed in 10-1 polycarbonate carboys with lake water (LW) at 5\%, 25\%, 50\% and $75 \%$ dilution to make up 101 , and then incubated as experimental microcosms. Duplicate microcosms were filled with 101 of $100 \%$ lake water or with $100 \%$ River water as lake control (LC) and River control (RC), respectively. Twelve microcosms were set up for each lake and placed in incubators filled with ambient LUMCON marina water. The carboy temperatures were stabilized by continuously pumping marina water through the holding chambers. The incubators and carboys were covered with screens to reduce light intensity by $50 \%$ using the same setup described in Ren et al. (2009). After mixing, water samples were taken from each carboy at 0,1 day, 2 days, and then every 2 days thereafter until the Chla concentration was depleted.

Temperature and solar radiation

We measured water temperature in the incubators and ambient water every $3 \mathrm{~h}$, and the incident solar 
radiation and photosynthetically active radiation (PAR) was recorded by the monitoring station at the LUMCON marine center (http://weather.lumcon.edu/ ). The light intensity in the holding chamber was measured below the surface water with and without screens using a LI-COR Inc. LI-189 Photometer and LI-193SA Sensor at the beginning of each experiment to ensure that the light intensity was $<50 \%$ after screening.

\section{Suspended particulate matter}

SPM water samples were filtered through pre-weighed $\mathrm{GF} / \mathrm{F}$ filters that were pre-combusted at $450^{\circ} \mathrm{C}$ for $24 \mathrm{~h}$. The filters with filtrate were first dried at 40 to $60^{\circ} \mathrm{C}$ for $12 \mathrm{~h}$, weighed, and then transferred to an $\mathrm{Al}$ cup and combusted at $450^{\circ} \mathrm{C}$ for $24 \mathrm{~h}$. The filters were weighed again after cooling to room temperature; the weight of the inorganic suspended matter was estimated by subtracting the pre-filtration filter weights. The concentration of organic suspended matter was calculated using the weight difference between the dried and combusted filters.

Nutrients

Samples for nutrient concentration measurements were filtered through $0.2-\mu \mathrm{m}$ pore size polycarbonate filters, and the filtrates were frozen immediately. Inorganic nutrients were analyzed on a Lachat QuickChem 8000 Flow Injection Analyzer, using the Lachat Methods approved by USEPA: method 31-107-06-1-B for ammonium, method 31-107-04-1-C for nitrate + nitrite, and method 31-115-01-1-H for soluble reactive phosphorus (SRP), and method 31-11427-1-C for silicate.

\section{Chlorophyll $a$}

Water samples for Chl $a$ analysis were filtered through Whatman GF/F filters. The filters were fixed in $5 \mathrm{ml}$ of a mixed solvent of DMSO (dimethyl sulfoxide): $90 \%$ acetone (40:60 by volume), and extracted for at least $2 \mathrm{~h}$ in the dark (Lohrenz et al., 1999). The extracts were measured on a Turner Model 10 fluorometer before and after acidification with $10 \% \mathrm{HCl}$ (Parsons et al., 1984). The fluorometer was calibrated for Chl $a$ against a dilution series of a chemical supply house Chla standard measured on a spectrophotometer.

Phytoplankton species composition

Phytoplankton samples were preserved in $0.5 \%(\mathrm{v} / \mathrm{v})$ glutaraldehyde and size-fractionated by filtration onto $0.2-, 3-$, and $8-\mu \mathrm{m}$ polycarbonate filters. The latter two fractions were stained with $0.03 \%$ proflavine hemisulfate, and the $0.2-$ to $3-\mu \mathrm{m}$ fractions were counted immediately after filtration. The $>8-\mu \mathrm{m}$ fraction was frozen and counted later. All samples were counted using an Olympus BH2-RFCA epifluorescence microscope equipped with a blue and green excitation light and transmitted light (Dortch et al., 1997; Ren et al., 2009). All algae were identified to the lowest taxonomic level possible and unidentified diatoms were categorized as three size fractions $(<10 \mu \mathrm{m}$, $10-20 \mu \mathrm{m}$ and $>20 \mu \mathrm{m}$ ). The detection limit was approximately 500 to 1000 cells $1^{-1}$, depending on the volume filtered ( $2 \mathrm{ml}$ to $25 \mathrm{ml}$ ).

Algal biovolume was calculated using microscopic measurements of their dimensions, and a geometric model of algae (Hillebrand et al., 1999). The biovolume of each taxon or category was averaged from 15 or more measurements. Biovolume was used to compare fractions among the whole community. Cell density was used to determine bloom status of a species or changes over time.

\section{Calculation of Chla yield}

The yield of Chla $(Y)$ per unit of nutrient decrease ( $d \mathrm{DIN}, d \mathrm{P}$, and $d \mathrm{Si}$ ) was calculated based on the equation modified from the one for batch culture in Edwards et al. (2003, p. 1775, Eq. 6):

$Y=\frac{\left(X_{\max }-X_{\max } \_l c\right)-\left(X 0-X 0 \_l c\right)}{\left(S 0-S 0 \_l c\right)-\left(S t-S t \_l c\right)}$,

where $Y$ is the yield of Chl $a$; $X$ max, $X$ max $\_l c$ are the highest concentration of Chla in the experimental and lake control microcosms $(l c)$, respectively; $X 0, X 0 \_l c$ are the initial concentration of Chl $a$ in the experimental and lake control microcosms $(l c)$, respectively; St, $S t$ lc are the concentration of DIN, SRP, or Si at the time $t$ when the maximum Chl $a$ concentration was reached in the experimental and lake control 
microcosms, respectively; and $S 0, S 0 \_l c$ are the initial concentration of DIN, SRP, or $\mathrm{Si}$, in the experimental and control microcosms, respectively.

\section{Statistical analysis}

Excel software was used to develop linear correlations between the increase of Chla $(Y)$ and the removal of each respective nutrient DIN, SRP, and Si for each lake. A multiple linear regression model was used to explore relationships between the increase of Chl $a(Y)$ and the uptake of three nutrients $(d \mathrm{DIN}, d \mathrm{P}$, and $d \mathrm{Si}$ ) using the data from all experiments for each lake. The latter analysis was conducted using MATLAB 6.5 where $P<0.05$.

\section{Results}

Delivery of Mississippi River water to adjacent waterways

The DPD discharged intermittently during our experiments (Swenson et al., 2005; Das et al., 2012). In most sampling periods (spring, summer and fall of 2006), the DPD was delivering minimal, if any, fresh water, sediments and nutrients to lakes Cataouatche and Salvador (Fig. 2). The most substantial input of the Mississippi River into adjacent estuarine waters was in early February through mid to late-February, 2006, when the February 2006 experiments were conducted.

Initial lake conditions

The salinity of Lakes Cataouatche and Salvador ranged from 0.2 to $5.0 \mathrm{psu}$ in the four experiments (Table 2). The SPM concentrations were generally lower in Lake Salvador and the Secchi depths were higher in Lake Cataouatche (Table 2). The highest SPM concentration observed in both lakes was in February 2006 when the DPD daily discharge was at the highest during the experiments (Fig. 2). The concentration of SPM and Chla in Lac des Allemands was highest in May and August 2005 (Table 2) during seasonal expression of eutrophication. The water temperature in the microcosms and the daily peak solar radiation were also higher in spring and summer, and lower in fall and winter (Table 2).
The concentrations of DIN in all three lakes were similar, being lowest in May $2005(\leq 1 \mu \mathrm{M})$ and highest in February $2006(85 \mu \mathrm{M}$, Table 2$)$. The concentration of SRP was generally below $1.0 \mu \mathrm{M}$ in Lake Cataouatche and Lake Salvador in all seasons, while the SRP concentration in Lac des Allemands varied the most, with the highest in August 2005 $(>6 \mu \mathrm{M})$ and lowest in February $2006(0.4 \mu \mathrm{M})$. The initial concentration of $\mathrm{Si}$ in the lakes was highest in spring 2005 at $\geq 100 \mu \mathrm{M}$, and exceeded $50 \mu \mathrm{M}$ in all three lakes most of the time.

The initial concentrations of DIN and SRP in the Mississippi River were much higher than in the three lakes during the period of experimentation (Table 2) and generally higher in the lakes when the diversion was operating. This created, in general, higher nutrient concentrations at the beginning of the experiments as the RW replacement proportion increased. The highest DIN concentration in the Mississippi River was in May $2005(120 \mu \mathrm{M})$, which was about 120 to $>200$ times higher than that in the lakes. The concentration of $\mathrm{Si}$ in the Mississippi River was about 1 to 5 times higher than that in the lakes. However, in summer (August 2005), the concentration of $\mathrm{Si}$ in the river water dropped to $1.5 \mu \mathrm{M}$, which was lower than that in the lakes (Table 2), and close to the theoretical minimal threshold for $\mathrm{Si}$ uptake by phytoplankton (2 $\mu$ M, Egge \& Aksnes, 1992). When Mississippi River water was highest in Chla concentration, the biovolume fraction of diatoms of the phytoplankton community was at its highest.

The concentration of Chla at the beginning of the experiments varied seasonally in the lakes and the Mississippi River (Table 2). In general, the Chla concentration in Lake Cataouatche was higher than that in Lake Salvador. An extremely high Chla concentration $\left(>200 \mu \mathrm{g}^{-1}\right.$ ) was documented in May 2005 in Lake Cataouatche. The Chla concentration in Lac des Allemands was generally high in August and November, at $>80$ and $140 \mu \mathrm{g}^{-1}$, respectively, but was reduced to $17 \mu \mathrm{g} \mathrm{l}^{-1}$ in February (Table 2). The concentration of Chla in the Mississippi River was generally lower than that in the lakes.

\section{Development of Chla in microcosms}

The time series of Chla concentration in the control and experimental microcosms are in Fig. 3. The addition of Mississippi River water promoted a higher 
Table 2 The hydrological conditions, initial concentration of nutrients $\left(\mu \mathrm{mol} 1^{-1}\right)$ and chlorophyll $a\left(\right.$ Chl $a$, $\left.\mu \mathrm{g} 1^{-1}\right)$ of the lakes and Mississippi River, and temperature and solar radiation during the experiments from May 2005 to February 2006

\begin{tabular}{|c|c|c|c|c|c|c|c|c|c|c|c|c|c|}
\hline & \multirow[t]{2}{*}{$\begin{array}{l}\text { Salinity } \\
\text { (psu) }\end{array}$} & \multirow[t]{2}{*}{$\begin{array}{l}\text { Secchi } \\
\text { depth }(m)\end{array}$} & \multirow[t]{2}{*}{$\begin{array}{l}\text { SPM } \\
\left(\mathrm{mg} \mathrm{l}^{-1}\right)\end{array}$} & \multicolumn{4}{|c|}{ Lake water (initial) } & \multicolumn{4}{|c|}{$\begin{array}{l}\text { Mississippi River } \\
\text { (initial) }\end{array}$} & \multirow[t]{2}{*}{$\begin{array}{l}\text { Temperature } \\
\left({ }^{\circ} \mathrm{C}\right)\end{array}$} & \multirow[t]{2}{*}{$\begin{array}{l}\text { Solar radiation } \\
\left(\mathrm{W} \mathrm{m}^{-2}\right)\end{array}$} \\
\hline & & & & DIN & SRP & $\mathrm{Si}$ & Chla & DIN & SRP & $\mathrm{Si}$ & Chla & & \\
\hline \multicolumn{14}{|c|}{ Lake Cataouatche } \\
\hline May05 & 0.2 & 0.6 & 5.8 & 1.0 & 0.2 & 20 & 208 & 128 & 1.5 & 93 & 6.9 & $25-30$ & 937-977 \\
\hline Aug05 & 0.2 & 0.8 & 8.7 & 2.4 & 0.6 & 111 & 25 & 52 & 1.9 & 1.5 & 61 & $30-33$ & 939-1007 \\
\hline Nov05 & 3.0 & 0.5 & 19 & 6.4 & 0.5 & 90 & 29 & 86 & 1.9 & 111 & 12 & $15-19$ & $496-709$ \\
\hline Feb06 & 0.3 & 0.3 & 84 & 85 & 0.5 & 76 & 42 & 88 & 2.0 & 112 & 13 & $12-19$ & $94-865$ \\
\hline \multicolumn{14}{|c|}{ Lake Salvador } \\
\hline May05 & 0.2 & 0.9 & 6.0 & 0.4 & 0.2 & 71 & 11 & 119 & 1.5 & 104 & 11 & $28-32$ & $795-941$ \\
\hline Aug05 & 0.3 & 1.7 & 2.3 & 2.8 & 0.6 & 100 & 15 & 52 & 1.9 & 1.5 & 61 & $30-33$ & 939-1007 \\
\hline Nov05 & 5.0 & 1.4 & 4.7 & 18 & 0.9 & 78 & 12 & 86 & 1.9 & 111 & 12 & $15-19$ & $496-709$ \\
\hline Feb06 & 1.4 & 0.4 & 53 & 53 & 1.0 & 79 & 21 & 88 & 2.0 & 112 & 13 & $12-19$ & $94-709$ \\
\hline \multicolumn{14}{|c|}{ Lac des Allemands } \\
\hline May05 & 0.1 & 0.3 & 68 & - & - & - & - & - & - & - & - & - & - \\
\hline Aug05 & 0.1 & 0.3 & 27 & 0.2 & 6.4 & 193 & 83 & 46 & 1.1 & 1.4 & 34 & $31-33$ & $653-944$ \\
\hline Nov05 & 0.4 & 0.9 & 9.1 & 12 & 1.2 & 25 & 148 & 98 & 2.8 & 83 & 7.0 & $10-14$ & $146-680$ \\
\hline Feb06 & 0.23 & 1.0 & 8.5 & 20 & 0.4 & 50 & 17 & 93 & 2.7 & 108 & 8.7 & $15-21$ & $261-855$ \\
\hline
\end{tabular}

biomass and longer growth period for phytoplankton in the experimental microcosms, even when the initial Chl $a$ concentration was high in lakes, such as in the experiments on Lake Cataouatche starting May 2005, and in Lac des Allemands starting in August 2005 and November 2005 (Table 2). There was a significant linear increase in Chla concentration with a higher RW/LW mixing ratio in all Lake Cataouatche and Lake Salvador microcosms (Table 3). The Chla increase (the difference between the initial and peak concentration of $\mathrm{Chl} a$ ) corresponding to a $1 \% \mathrm{RW}$ replacement volume into ambient water varied from 1.1 to $2.9 \mathrm{~g} \mathrm{l}^{-1}$ in the Lake Cataouatche experiments, and 0.95 to $2.0 \mu \mathrm{g}^{-1}$ in the Lake Salvador experiments (Table 3). The relationship between Chl $a$ increase and \% RW varied in the three Lac des Allemands experiments. In August 2005, the concentration of the Chl $a$ in the $75 \%$ RW microcosms started high $\left(>100 \mu \mathrm{g} \mathrm{l}^{-1}\right)$ and did not show much increase compared to that in the lake controls (LC), and the relationship appeared to be polynomial. The concentration of Chla, however, increased either linearly or exponentially with an increase in the RW replacement time in November and February, respectively (Table 3).
Inverse correlation between Chla increase and nutrient decrease

The nutrient concentration in microcosms decreased gradually over the 3- to 7-day incubation period (Figs. S1-S3), mirroring the increase in Chla concentration (Fig. 3). In general, the Chla concentration decreased after the DIN or SRP, or both were exhausted in the microcosms (Figs. S1-S3). There was a significant linear correlation between the increase in Chla concentration $(Y)$ and the decrease of nutrient concentrations ( $d \mathrm{DIN}, d \mathrm{P}$, and $d \mathrm{Si}$ ). The Chl $a$ increase in Lake Cataouatche and Lake Salvador was significantly related to $d \mathrm{DIN}$ and $d \mathrm{Si}$, but less significantly related to $d \mathrm{P}$ (Table 4). Among the three nutrients, $d \mathrm{DIN}$ was significantly correlated to $d \mathrm{Si}$, but less so with the $d \mathrm{P}$ in Lake Cataouatche, whereas $d \mathrm{DIN}$ in Lake Salvador was more significantly coupled with $d \mathrm{P}$ than with $d$ Si (Table 4). For Lac des Allemands, when data from all the experiments were considered, the increase of Chla was significantly correlated with decreasing $d \mathrm{P}$, but had a weak or insignificant linear correlation with $d \mathrm{Si}$ and $d \mathrm{DIN}$. When only the November 2005 and February 2006 data were considered, the linear correlation between 
Lake Cataouatche
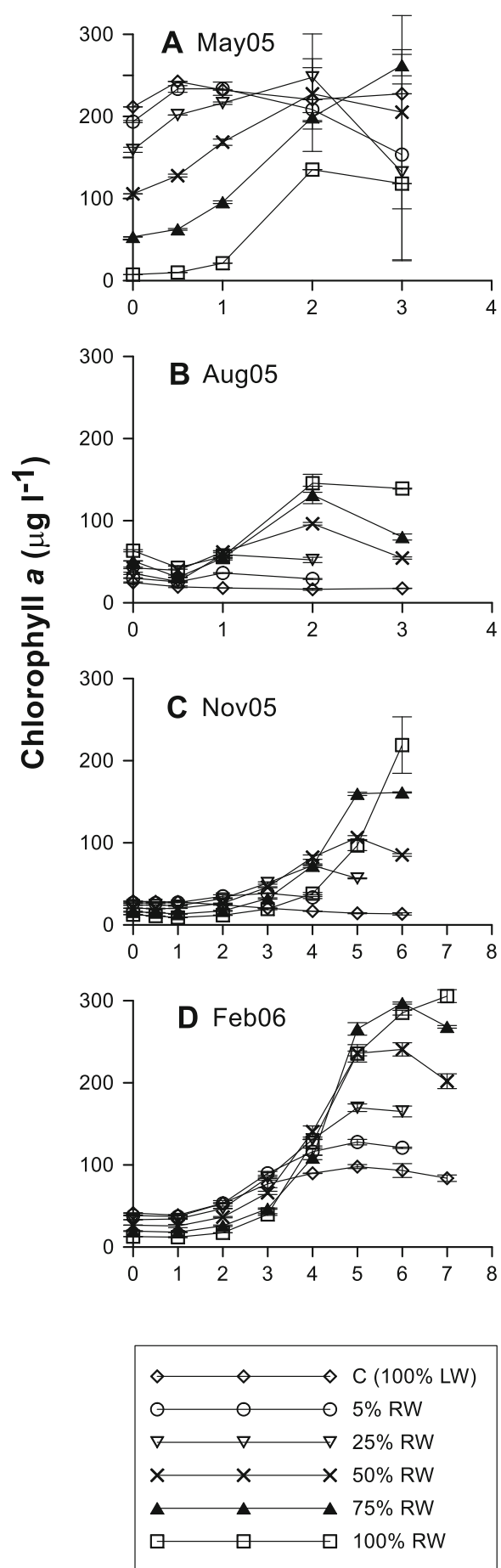

Lake Salvador

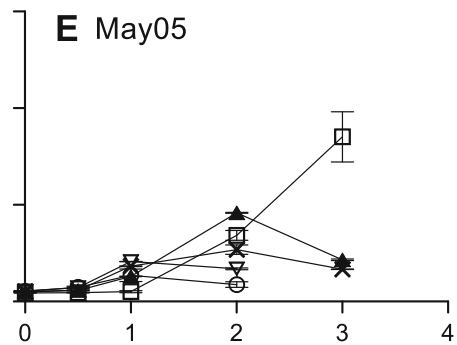

F Aug05
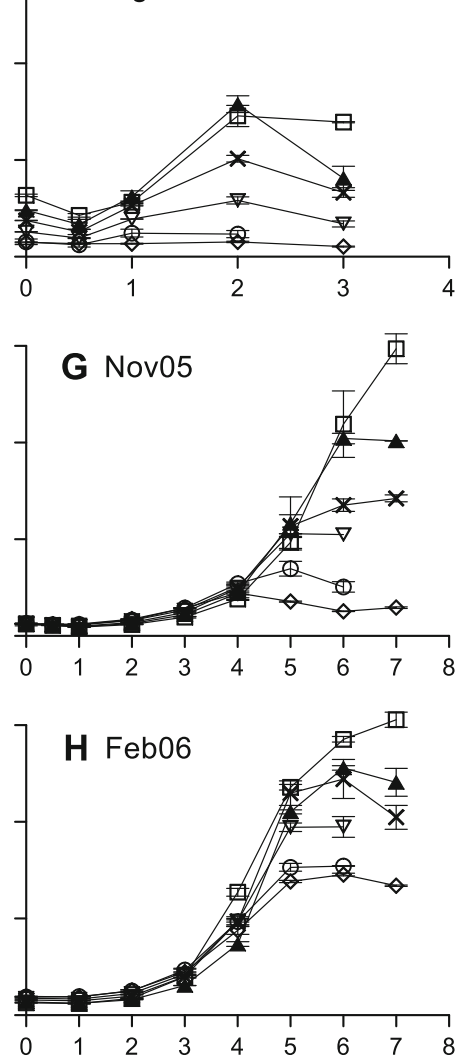

Incubation time (days)

\section{Lac des Allemands}

I May05

no data
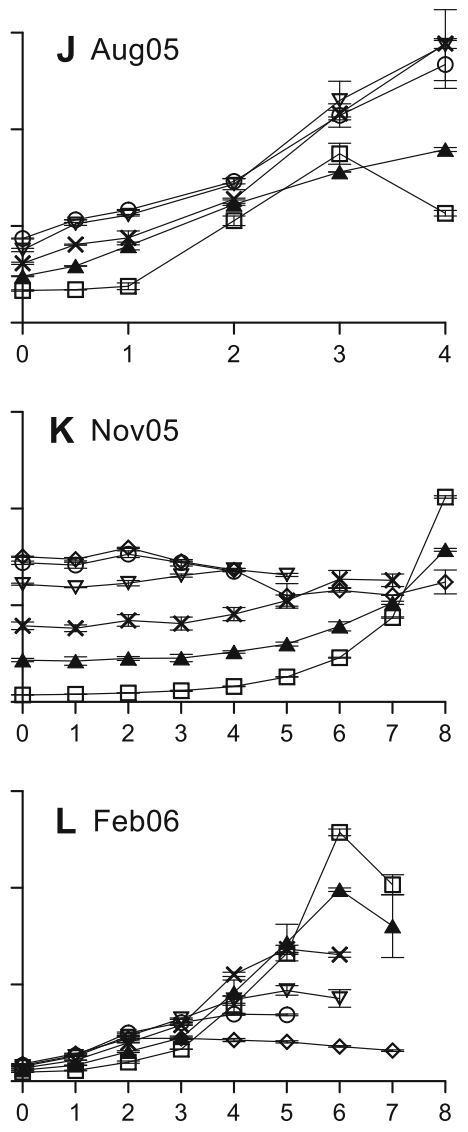
Table 3 Correlation of Chl $a$ increase with the percentage of Mississippi River water mix in the experiments of Lake Cataouatche, Lake Salvador and Lac des Allemands

\begin{tabular}{llccc}
\hline Lake & May05 & Aug05 & Nov05 & Feb06 \\
\hline Cataouatche & $Y=2.3 \times X+28$ & $Y=1.1 \times X-3.5$ & $Y=1.9 \times X-3.2\left(R^{2}=0.99\right)$ & $Y=2.9 \times \mathrm{X}+66$ \\
& $\left(R^{2}=0.97\right)$ & $\left(R^{2}=0.99\right)$ & & $\left(R^{2}=0.99\right)$ \\
Salvador & $Y=0.95 \times X+5.4$ & $Y=1.4 \times X-1.4$ & $Y=2.0 \times X+38$ & $Y=1.6 \times X+131$ \\
& $\left(R^{2}=0.95\right)$ & $\left(R^{2}=0.99\right)$ & $\left(R^{2}=0.97\right)$ & $\left(R^{2}=0.96\right)$ \\
des & No data & $Y=1.5 \times X+160$ & $\ln (\mathrm{Y})=0.04 \times X+2.0$ & $Y=2.0 \times X+32$ \\
Allemands & & $\left(R^{2}=0.82\right)$ & $\left(R^{2}=0.98\right)$ & $\left(R^{2}=0.98\right)$ \\
\hline
\end{tabular}

$X$ percentage of river water $(\% \mathrm{RW}), R^{2}$ coefficient of correlation

Table 4 Linear correlation coefficient $(R)$ between the Chl $a$ yield $(Y)$ and the nutrient decrease ( $d \mathrm{DIN}$, $d \mathrm{Si}, d \mathrm{P})$ from experiments on the three lakes

\begin{tabular}{|c|c|c|c|c|}
\hline Lake & $Y$ & $\mathrm{dDIN}$ & $\mathrm{dSi}$ & Equation \\
\hline \multicolumn{5}{|c|}{ Lake Cataouatche } \\
\hline$d \mathrm{DIN}$ & 0.86 & n.s. & n.s. & $Y=2.4 \times d \mathrm{DIN}-12$ \\
\hline$d \mathrm{Si}$ & 0.70 & 0.69 & n.s. & $Y=1.0 \times d \mathrm{Si}-5.4$ \\
\hline$d \mathrm{P}$ & $0.52 * *$ & $0.50 * *$ & $0.64 *$ & $Y=88 \times d \mathrm{P}+22$ \\
\hline \multicolumn{5}{|c|}{ Lake Salvador } \\
\hline$d \mathrm{DIN}$ & 0.86 & n.s. & n.s. & $Y=2.8 \times d \mathrm{DIN}-13$ \\
\hline$d \mathrm{Si}$ & 0.79 & $0.60 *$ & n.s. & $Y=1.5 \times d \mathrm{Si}+11$ \\
\hline$d \mathrm{P}$ & 0.79 & 0.76 & 0.71 & $Y=105 \times d \mathrm{P}-17$ \\
\hline \multicolumn{5}{|c|}{ Lac des Allemands } \\
\hline \multicolumn{5}{|c|}{ a. Based on experiments in Aug05, Nov05 and Feb06 } \\
\hline$d \mathrm{DIN}$ & $0.03^{\#}$ & n.s. & n.s. & \\
\hline$d \mathrm{Si}$ & $0.51 * *$ & $0.44^{\#}$ & n.s. & \\
\hline$d \mathrm{P}$ & 0.81 & $-0.36^{\#}$ & $0.46^{\#}$ & $Y=43 \times d \mathrm{P}+29$ \\
\hline \multicolumn{5}{|c|}{ b. Based on experiments in Nov05 and Feb06 (Aug05 excluded) } \\
\hline$d \mathrm{DIN}$ & $0.81 *$ & n.s. & n.s. & $Y=2.4 \times d \mathrm{DIN}-25$ \\
\hline$d \mathrm{Si}$ & $0.84 * *$ & 0.87 & n.s. & $Y=1.6 \times d \mathrm{Si}+4.5$ \\
\hline$d \mathrm{P}$ & 0.88 & $0.73 * *$ & $0.81 *$ & $Y=93 \times d \mathrm{P}-26$ \\
\hline
\end{tabular}

n.s. no statistics

$* P<0.01 ; * * P<0.05$;

${ }^{\#}$ Not statistically significant; others:

$P<0.001$
Phytoplankton community composition

Chl $a$ and $d \mathrm{DIN}$, and those among three nutrients became statistically significant (Table 4 , case b).

The multiple regression models described the increase of Chla concentration $(Y)$ in lakes corresponding to riverine nutrient inputs (Fig. 4). The coefficient of determination between the actual and predicted Chla concentration suggested that the change of DIN, SRP and $\mathrm{Si}(d \mathrm{DIN}, d \mathrm{P}$, and $d \mathrm{Si}$ ) could explain $82 \%$ and $86 \%$ of the Chla increase in lakes Cataouatche and Salvador, and Lac des Allemands, respectively (Fig. 4).
The major phytoplankton groups in the lakes included diatoms, cyanobacteria, chlorophytes, cryptomonads, and euglenoids. Their biovolume fractions at the beginning of the experiments and at the Chla peak are shown in Figs. 5, 6, 7. The lake phytoplankton assemblages were dominated by cyanobacteria in May 2005, accounting for $98 \%$ and $78 \%$ of the total biovolume in Lake Cataouatche and Lake Salvador, respectively. The dominant cyanobacterium was $A n-$ abaena cf. circinalis, a $\mathrm{N}$-fixing and potentially toxic taxon. Diatoms, mainly Cyclotella meneghiniana and Aulacoseira granulata, were dominant in August 2005 and February 2006, and accounted for $50 \%$ to $75 \%$ of 

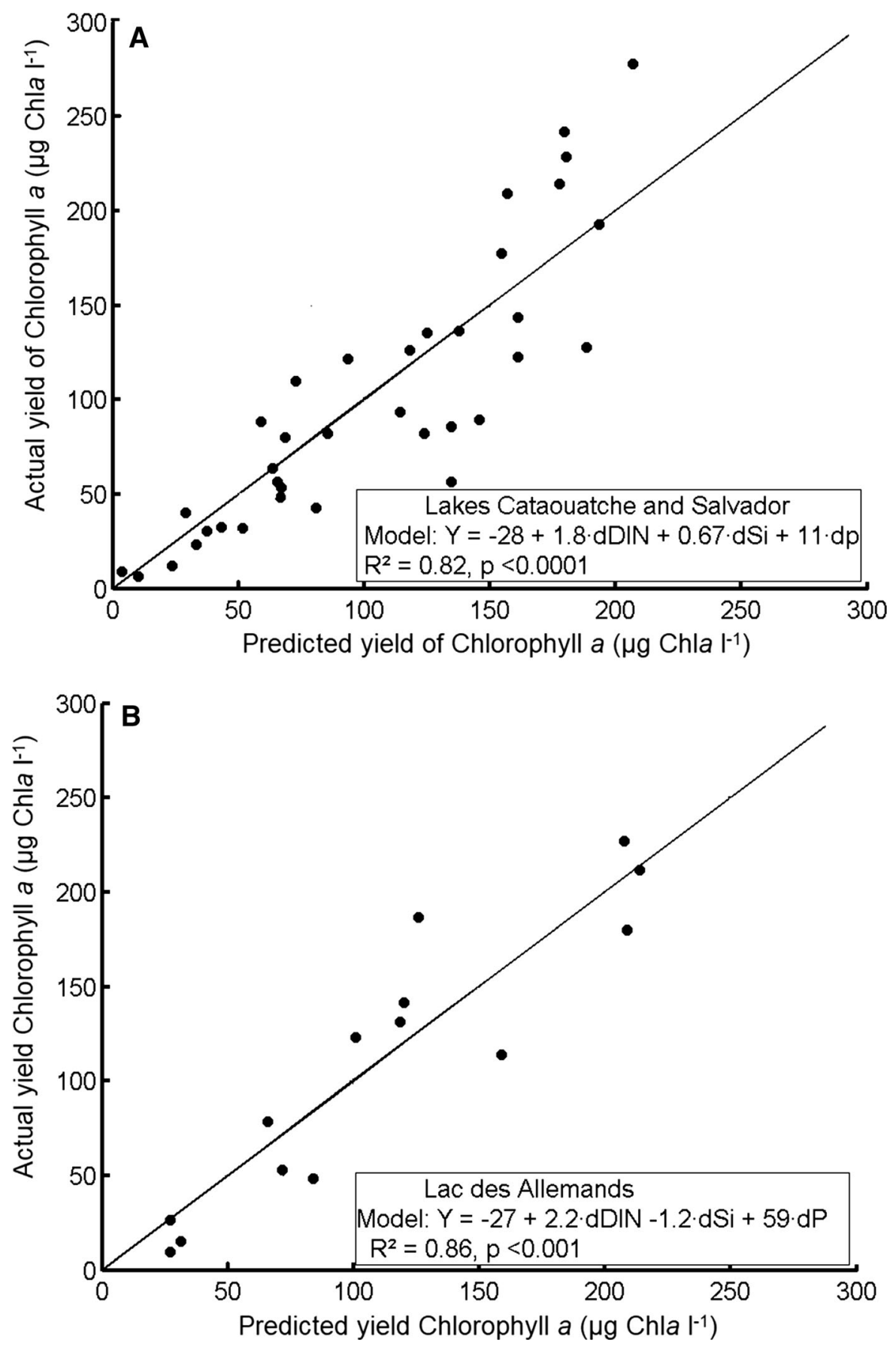

Fig. 4 The prediction models of Chla yield based on multiple linear regression analysis and the comparison with experimental results. $Y$ : chlorophyll yield in $\mu \mathrm{g} 1^{-1}, d D I N, d S i$, and $d P$

total biovolume (Figs. 5 and 6). An autotrophic ciliate, Myrionecta rubra (syn. Mesodinium rubrum), was abundant in November 2005, reaching up to $2.5 \times 10^{5}$ decreases of dissolved inorganic nitrogen (DIN), silicate ( $\mathrm{Si}$ ) and soluble reactive phosphate $(\mathrm{P})$, all in $\mu \mathrm{mol} 1^{-1}$. A Lakes Cataouatche and Salvador. B Lac des Allemands

cells $\mathrm{L}^{-1}$, and accounted for $>50 \%$ of the total biovolume of taxa in Lake Cataouatche and Salvador (Figs. 5 and 6). Cyanobacteria taxa were the largest 
proportion, by biovolume, of the phytoplankton community in Lac des Allemands at the beginning of all experiments. The August 2005 and November 2005 community was dominated by N-fixing Anabaena cf. circinalis and Anabaena annelid, together with $\mathrm{Mi}$ crocystis spp., and accounted for $>80 \%$ of total biovolume (Fig. 7). Microcystis spp. increased in proportion of the phytoplankton community in February 2006, when it accounted for more than $60 \%$ of the total biovolume (Fig. 7). Details of the microcosms from Lake Salvador in November 2005 demonstrated shifts in species and relative proportions of the phytoplankton community in the Mississippi River water additions (Figs. 6 and 8). While the biovolume of cyanobacteria was a small proportion of the phytoplankton community, the densities of potentially harmful cyanobacteria reached or were near bloom densities after 7 days after the 50\% RW addition.

Except for the dominant species mentioned above, other frequently detected species in the lakes included diatoms Skeletonema spp., Melosira spp., Fragilaria sp., Stephanodiscus sp., Asterionella spp. and Nitzschia spp. and the cyanobacteria Anabaenopsis sp., Aphanizomenon sp., Cylindrospermopsis sp., and Raphidiopsis curvata. Other filamentous cyanobacteria, such as Planktolyngbya and Jaaginema, and colonial coccoid Merismopedia spp., were also frequently detected and sometimes in high densities. Chlorophytes, including Actinastrum spp., Closterium spp., Scenedesmus spp. and Pediastrum spp., were commonly present, but did not make up a high biovolume fraction in the initial composition of the lakes. The dominant phytoplankton in the Mississippi River were diatoms in all seasons and accounted for nearly $80 \%$ of the total biovolume. The River diatoms included Cyclotella meneghiniana, Stephanodiscus medius, and Aulacoseira spp.

We identified three general phytoplankton community shifts in the experiments based on the initial LW compositions and subsequent changes

Group one consisted of six experiments, including November 2005 and February 2006 of Lake Cataouatche, May 2005, November 2005 and February 2006 of Lake Salvador, and February 2006 of Lac des Allemands. In all these experiments, the initial Chla concentrations were similar in the lakes and the
Mississippi River, and the phytoplankton assemblages in the microcosms were dominated by diatoms from the beginning to the end of the experiments (Figs. 5, 6, 7). In November 2005, in Lake Cataouatche and Lake Salvador, Myrionecta rubra made up more than 50\% of the biovolume biomass, but due to the large cell size, its cell density was actually one to two magnitudes lower than that of diatoms.

Group two consisted of lakes Cataouatche and Salvador in August 2005, featuring high Chla and low $\mathrm{Si}$ in the River water at the beginning of the experiments (Table 2). Diatom growth in the microcosms was sustained from high $\mathrm{Si}$ in the lake water, and the percent of biovolume as diatoms increased with higher River water replacement (Figs. 5B and 6B). However, because the Mississippi River water contained a low Si concentration, the phytoplankton growth in the $50 \%$ and $75 \%$ RW microcosms may have undergone $\mathrm{Si}$ limitation leading to an increase in the percentage of chlorophytes at the end of the experiment (Figs. 5B and 6B).

Group three was composed of data from the May 2005 Lake Cataouatche (Fig. 5A), and August 2005 and November 2005 Lac des Allemands experiments (Fig. 7B, C), and shared two main characteristics: (1) the initial Chl $a$ in the lakes was much higher than that in the River (Table 2); and (2) the lake phytoplankton communities were dominated by cyanobacteria, whereas the Mississippi River phytoplankton was dominated by diatoms. However, the change in nutrients, Chla, and phytoplankton composition differed among the experiments. In the May 2005 Lake Cataouatche experiment, the DIN and SRP were taken up within 1 to 2 days in most microcosms (Fig. S1), while the Chla peak occurred 1 or 2 days after the nutrient depletion (Fig. 3A), and phytoplankton were dominated by cyanobacteria (Fig. 5A). In the August 2005 Lac des Allemands experiment, the concentration of Chl $a$ increased gradually to the end of the experiment, but no distinct peak was detected (Fig. 3J), and cyanobacteria were dominant in all microcosms, including the initial LW (Fig. 7B). The increase of Chl $a$ was relatively slow in the November 2005 Lac des Allemands experiment when compared to other experiments (Fig. 3K). The diatom fraction increased as the increasing Mississippi River volume percentage brought in Mississippi River diatoms and nutrients (Fig. 7C). 


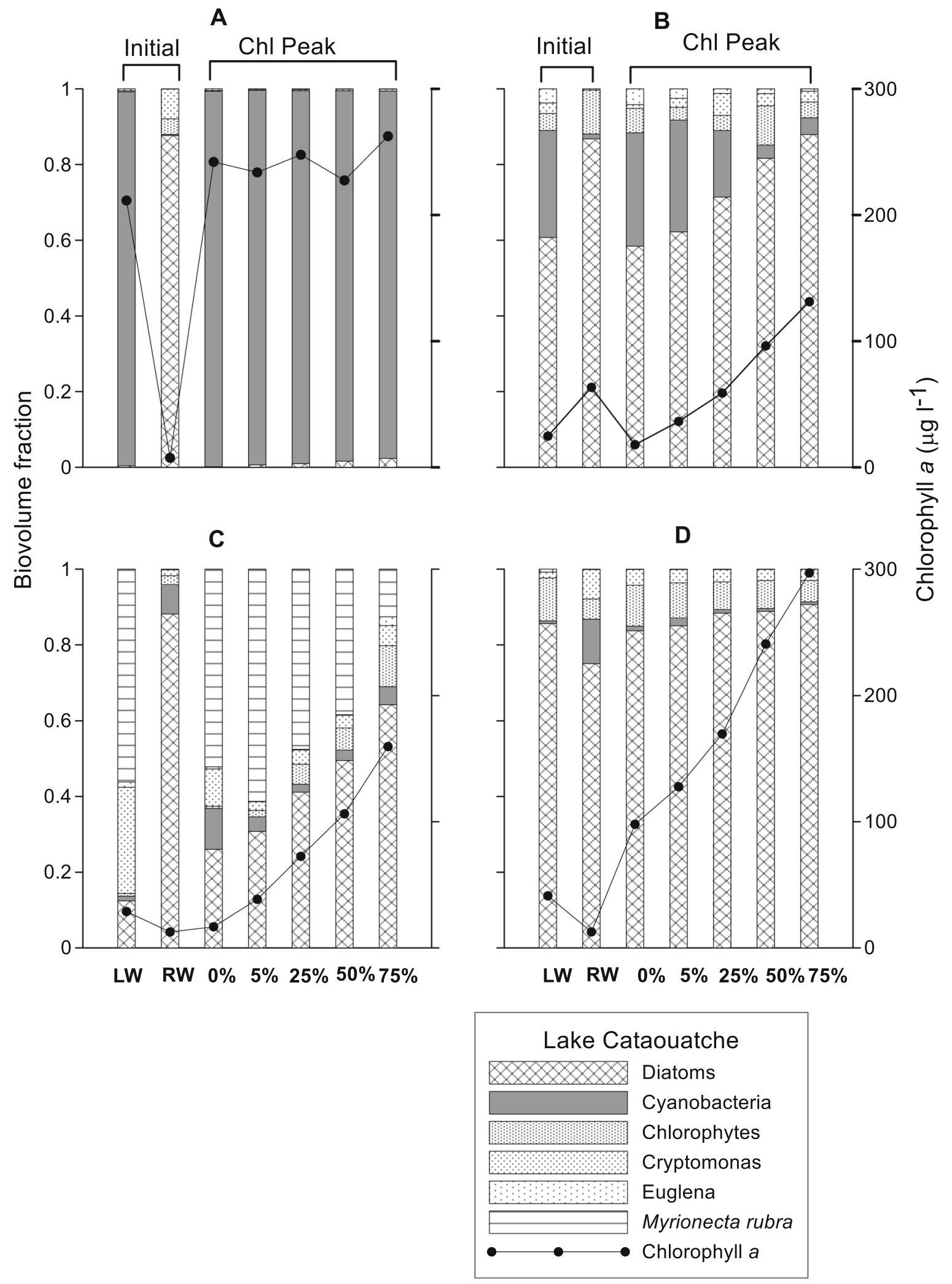


४Fig. 5 Biovolume fractions of major phytoplankton groups and Chla concentration in the initial Lake and River water and the microcosms at the Chla peak in the experiments of Lake Cataouatche in May 2005 (A), August 2005 (B), November 2005 (C), and February 2006 (D)

\section{Discussion}

The general result from the four sets of microcosm mixing experiments is that introducing Mississippi River water to the upper Barataria Basin will yield a predictable increase in phytoplankton biomass and changes in species composition that will often include toxic cyanobacteria. These robust results must be considered as strong inferences about ecosystem behavior, while acknowledging that there are artifacts inherent to microcosm experiments that do not represent all conditions in the environment.

\section{Chlorophyll $a$ yield}

The concentration of nutrients in the Mississippi River was usually much higher than in the lakes and provided an important nutrient source for phytoplankton growth in lakes Cataouatche and Salvador, as indicated by the significant linear correlation between the Chl $a$ increase, the River/Lake water mixing ratios (Table 3), and the decrease in DIN, SRP, and Si concentrations. Even a small amount of Mississippi River water introduced to these lakes resulted in a significant increase in phytoplankton biomass in the form of Chl $a$. The higher coefficient of determination $\left(R^{2}\right)$ between the Chl $a$ increase and $d \mathrm{DIN}$ compared to $d \mathrm{P}$ and $d \mathrm{Si}$ indicated a stronger role for $\mathrm{N}$ on the phytoplankton growth compared to SRP and $\mathrm{Si}$. These results are consistent with results from our previous bioassay experiments demonstrating that $\mathrm{N}$ was the sole or primary limiting nutrient in these lakes, although $\mathrm{N}$ and $\mathrm{P}$ co-limitation sometimes occurred (Ren et al., 2009).

The Chl $a$ yield was about 2.4 and $2.8 \mu \mathrm{g} \mathrm{Chl} a \mu \mathrm{mol}$ $\mathrm{N}^{-1}$ for Lake Cataouatche and Lake Salvador, respectively (Table 4). The average yields are well within results from laboratory monoculture and mesocosm studies (1.3-3.2 $\mu \mathrm{g}$ Chla $\mu \mathrm{mol} \mathrm{N}^{-1}$ ) (Gowen et al., 1992). These values are also comparable to those from the batch culture study by Edwards et al. (2003), which showed that the maximum
Chl $a$ yield from available DIN at the bloom peak was $2.35 \mu \mathrm{g} \mathrm{Chla} \mu \mathrm{mol} \mathrm{N} \mathrm{N}^{-1}$. The bottom-up effects from nutrients are assumed to exceed those from the grazing (top-down) and other stressors (light and temperature were controlled) in controlling the increase phytoplankton biomass (Murrell et al., 2002; Wong et al., 2016). The Chla yield from these microcosm experiments is probably close to the maximum stimulation of phytoplankton growth in the lakes receiving River water from the DPD. The in situ phytoplankton growth, however, is influenced by hydrological and chemical processes, which modulate the potential Chl $a$ yields.

Lac des Allemands, while not receiving Mississippi River inputs, is similar to other Mississippi River deltaic plain lakes in being hypereutrophic and subject to nutrient-enriched watershed runoff, or possibly diverted river water in the future. The Chla increase in Lac des Allemands was only linear with increasing proportions of Mississippi River water when the initial lake Chla concentrations were relatively low, such as in February 2006.

\section{Nutrient co-limitation}

The significant linear correlation between the increasing Chl $a$ concentration and decreasing DIN, SRP, and $\mathrm{Si}$ concentrations, and the significant correlations among these nutrients (Table 4), suggests that all three nutrients are essential in regulating phytoplankton growth and community composition in the three lakes. The multiple linear regression models describe the quantitative relationships to predict phytoplankton biomass yield from nutrient concentrations (Fig. 4).

Three nutrient variables (DIN, SRP, and $\mathrm{Si}$ ) explained $76 \%-86 \%$ of the variations in Chla concentrations in the experimental systems. The lower significance of $d \mathrm{P}$ in Lake Cataouatche, when compared to Lake Salvador (Table 4), is due mainly to the results from the May 2005 experiment that used Lake Cataouatche water with high Chla, low DIN, and low SRP concentrations (Table 2). After mixing, the SRP was quickly taken up and depleted within the first $24 \mathrm{~h}$ in all microcosms, whereas the Chl $a$ concentration only peaked after 48 to $72 \mathrm{~h}$. The de-coupling of SRP uptake and Chla increase was observed previously (Ren et al., 2009), and can be explained by the luxury uptake of $\mathrm{P}$ that resulted from the cellular P-deficiency in phytoplankton cells. If the May 2005 experiment 

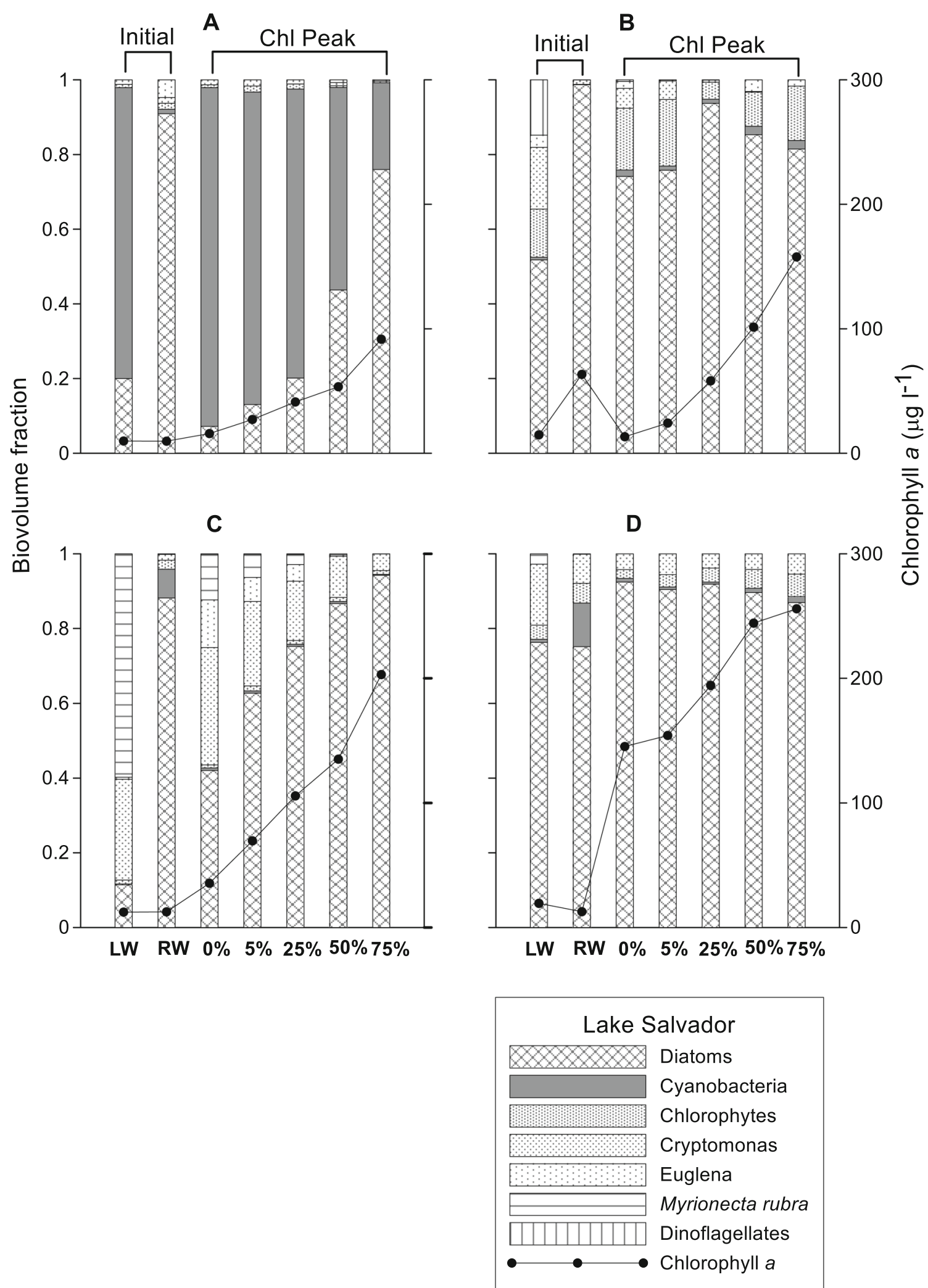
4Fig. 6 Biovolume fractions of major phytoplankton groups and Chla concentration in the initial Lake and River water and the microcosms at the Chla peak in the experiments of Lake Salvador in May 2005 (A), August 2005 (B), November 2005 (C), and February 2006 (D)

were excluded, the significance of the correlation between the Chla increase and the SRP decrease was higher for Lake Cataouatche $\left(R^{2}=0.7\right.$, equation not shown).

A comparison of the May 2005 Lake Cataouatche experiment and the Aug 2005 Lac des Allemands experiment is informative with regard to the available DIN and nitrogen-fixation. The phytoplankton community in May 2005 was dominated in density by $\mathrm{N}$-fixing Anabaena cf. circinalis in Lake Cataouatche $\left(2.9 \times 10^{8}\right.$ cells $\left.1^{-1}\right)$. But, $\mathrm{N}$-fixation did not seem to occur, because the Chla concentration decreased in the control and was correlated with the decrease of DIN ( $d \mathrm{DIN}) \quad\left(R^{2}=0.97, n=5\right)$. By comparison, the Chla concentration in the Aug 2005 Lac des Allemands experiment increased continuously despite the DIN concentration falling below the uptake threshold value and the significant decrease of $\operatorname{SRP}\left(R^{2}=0.74\right.$, $n=5$ ) (Figs. 3J, S3), indicating $\mathrm{N}$-fixation during the experiment.

The N-fixing Anabaena cf. circinalis was the numerically dominant species in the cyanobacterial community in Lake Cataouatche in May 2005 and in Lac des Allemands in Aug 2005 experiments. The ratio of heterocysts to vegetative cells $(\mathrm{H}: \mathrm{V})$ for $A$. cf. circinalis was similar in both lakes, and varied between 0.033 and 0.035 , which is consistent with results from earlier nutrient limitation bioassays (0.02-0.05, Ren et al., 2009). The H:V ratio, however, was low compared to other studies (0.06-0.10 in Lee \& Rhee, 1999; and Teaumroong \& Innok, 2002), indicating that Anabaena in these lakes may have a relatively low $\mathrm{N}$-fixation capacity. It is also possible that $\mathrm{N}$-fixation was inhibited by available ambient inorganic nitrogen in these lakes, especially ammonium $\left(\mathrm{NH}_{4}\right)$. Although the concentration of $\mathrm{NO}_{3+2}$ was as low as $0.1 \mu \mathrm{M}$ in both experiments, there was a big difference in the initial $\mathrm{NH}_{4}$ concentration. The $\mathrm{NH}_{4}$ concentration was about $0.9 \mu \mathrm{M}$ in May 2005 Lake Cataouatche. The fast regeneration of $\mathrm{NH}_{4}$ may have inhibited $\mathrm{N}$-fixation in Lake Cataouatche, as suggested by a previous study in Barataria Bay
(Madden et al., 1988). The initial concentration of $\mathrm{NH}_{4}$ was as low as $0.1 \mu \mathrm{M}$ in the Aug 2005 Lac des Allemands experiment, and Anabaena and other $\mathrm{N}$-fixing cyanobacteria appeared to have developed the ability to fix nitrogen. As a result, phytoplankton growth showed little correlation with the concentration of DIN in the microcosms. The hypothesis that ammonium may be an inhibiting factor to $\mathrm{N}$-fixation was also confirmed in the Nov 2005 experiment of Lac des Allemands. The initial Chla concentration was high, and cyanobacteria were dominant with $50 \%$ of Anabaena spp. and $45 \%$ of Microcystis spp. N-fixation seemed to be absent when the Chl $a$ concentration decreased after the depletion of DIN in the lake control microcosms where $80 \%$ of initial DIN was ammonium (Table 2).

The availability of dissolved silicate and the proportion to other dissolved inorganic nutrients are key factors regulating phytoplankton species competition and succession (Raven, 1983; Egge \& Aksnes, 1992; Milligan \& Morel, 2002; Turner et al., 2008). The significant correlation between the increase in Chl $a$ concentration and the uptake of Si, DIN, and SRP in both Lake Cataouatche and Lake Salvador (Table 4) suggests that diatoms dominated the new phytoplankton production in the microcosms. When lake diatoms were abundant, e.g., in Aug and Nov 2005 , and Feb 2006, the molar ratio of $\Delta \mathrm{Si}: \Delta \mathrm{DIN}$ calculated from the experiments was 1.07:1 $\left(R^{2}=0.79\right)$ for Lake Cataouatche and 1.33:1 $\left(R^{2}=0.76\right)$ for Lake Salvador. These data are comparable to the results from Brzezinski (1985) who showed that the $\mathrm{Si}: \mathrm{N}$ ratio of marine diatoms ranged between $\sim 0.8$ and 1.2:1 (with a mean value of 1.05) and varied with species composition and light conditions. In general, marine diatoms have less silica content per unit cell than freshwater species (Conley et al., 1989). The dominant diatom species in our study lakes included Cyclotella meneghiniana, Stephanodiscus medius, Aulacoseira ambigua, and A. granulate. These species generally have a higher silica content per cell than most marine diatoms, which may explain that the $\Delta \mathrm{Si}: \Delta \mathrm{DIN}$ ratios from our experiments are slightly higher compared to previous studies (Brzezinski, 1985). In May 2005, when phytoplankton was dominated by the cyanobacterium Anabaena cf. circinalis, the $\Delta \mathrm{Si}: \Delta \mathrm{DIN}$ ratio decreased to $0.48: 1$ $\left(R^{2}=0.70\right)$ and $0.40: 1 \quad\left(R^{2}=0.81\right)$ in Lake Cataouatche and Lake Salvador, respectively. Using the 

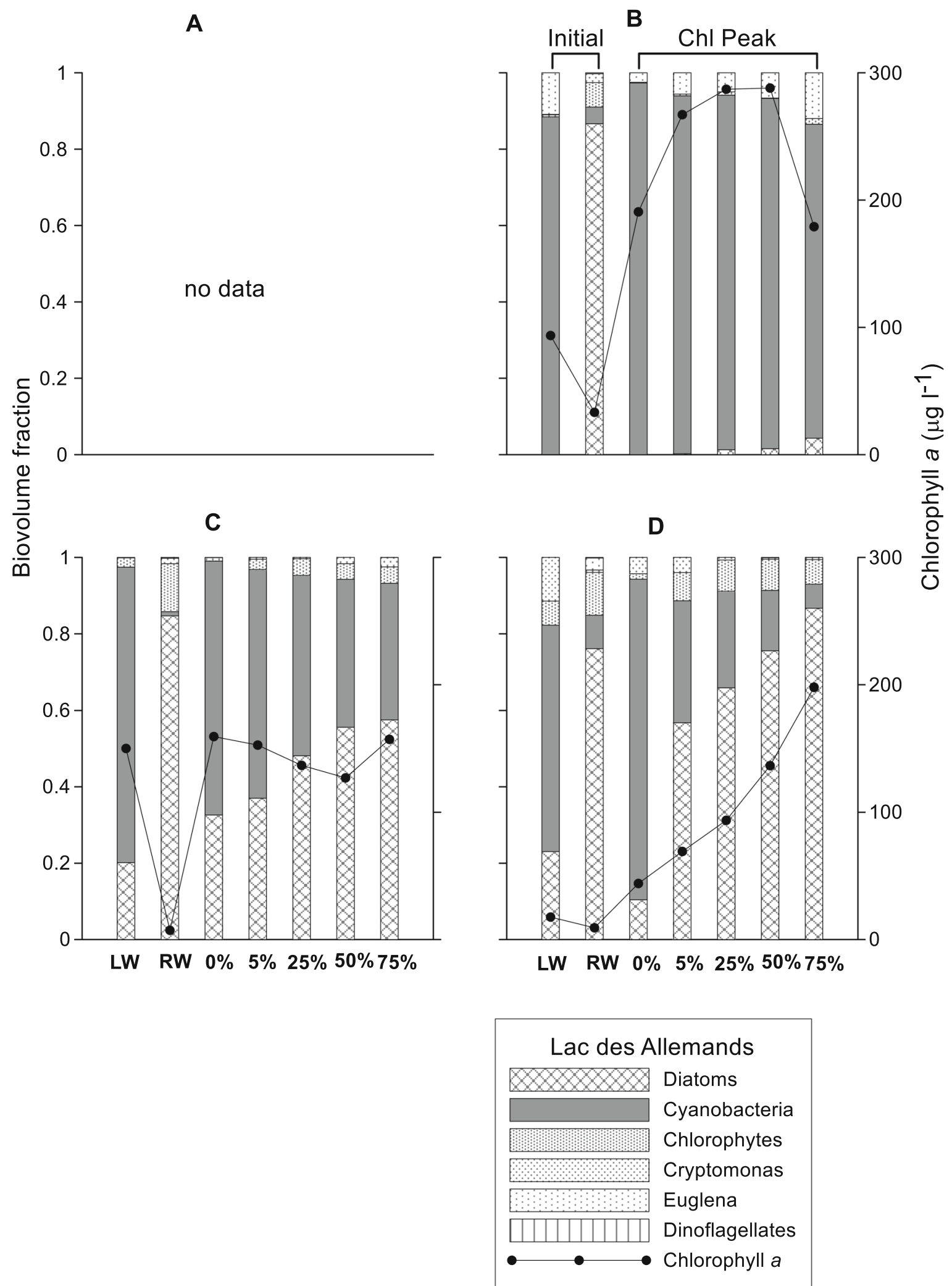
4Fig. 7 Biovolume fractions of major phytoplankton groups and Chla concentration in the initial Lake and River water and the microcosms at the Chla peak in the experiments of Lac des Allemands in May 2005 (A), August 2005 (B), November 2005 (C) and February 2006 (D)

$\Delta \mathrm{Si}: \Delta \mathrm{DIN}$ ratio from the other three seasons as references (1.05:1 for Lake Cataouatche and 1.33:1 for Lake Salvador), we estimated that approximately half and one-third of the chlorophyll yield was by diatoms. Cyanobacteria successfully competed with diatoms and took up more than half of the riverine DIN for their growth in both lakes in May 2005. However, the Mississippi River water, as in summer 2005, contained a high proportion of diatoms, and a lower $\mathrm{Si}$ concentration than the uptake threshold $(2 \mu \mathrm{M}$, Egge \& Aksnes, 1992). The input of Mississippi River water can therefore cause severe Si limitation on diatom growth and promote the growth of non-diatom taxonomic groups in the lakes when under a continuous input of $\mathrm{N}$ and $\mathrm{P}$. Furthermore, the high loading of SPM from the Mississippi River may lead to light limitation for most phytoplankton species. Some cyanobacteria taxa, such as Anabaena, Microcystis, and Aphanizomenon, have selective advantages over light limitation because of their buoyancy that is regulated by gas vesicles (Walsby et al., 1997). This buoyancy provides a competitive advantage in turbid lakes with dense phytoplankton biomass (Chorus \& Bartram, 1999). A recent study on whole lake $\mathrm{N}$ fertilization showed that the new phytoplankton primary production derived from $\mathrm{N}$ enrichment may not be efficiently transferred up to zooplankton, resulting in potential accumulation of phytoplankton biomass (Deininger et al., 2017). For these reasons, the input of Mississippi River water via diversions can support phytoplankton biomass increases and shifts from diatoms to non-diatoms. When the Bonnet Carré Spillway was opened in 1997 as flood prevention for the city of New Orleans and introduced Mississippi River water into Lake Pontchartrain, a bloom developed (maximum Chla concentration of $855 \mu \mathrm{g}$ Chla $1^{-1}$ ) composed of Anabaena and Microcystis whose toxicity was sufficiently high to lead to a health advisory that closed the lake to recreational contact (Dortch et al., 1999; Turner et al., 2004). Similarly, the high Chla concentration $\left(205 \mu \mathrm{g}^{-1}\right)$ and a dense

\section{Initial}

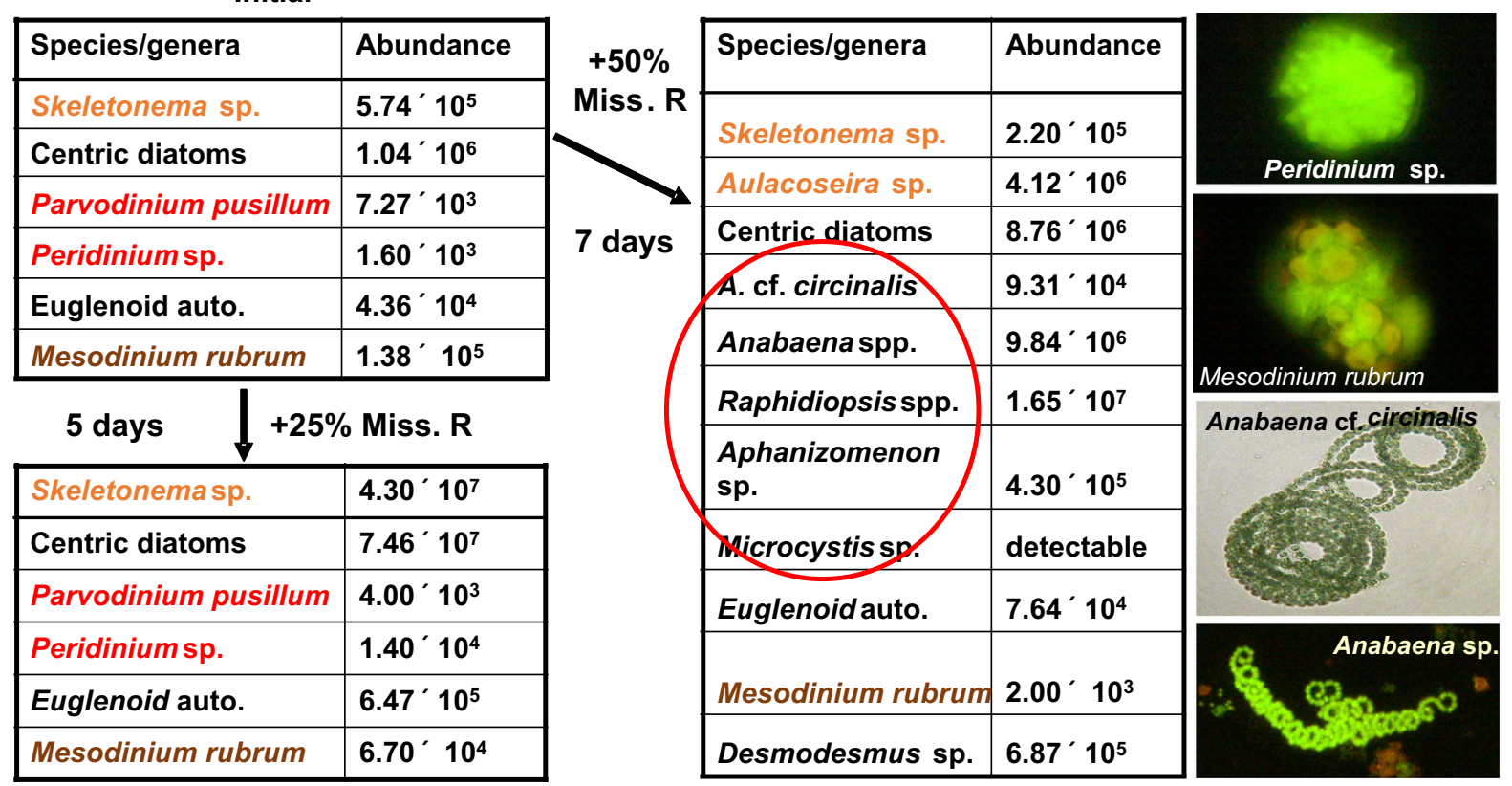

Fig. 8 Changes in phytoplankton taxa and their cell density for Lake Salvador in November 2005. Quantities are cell numbers per liter. Orange fonts represent diatoms; red fonts represent dinoflagellates, and brown fonts represent the autotrophic ciliate
Mesodinium rubrum (syn. Myrionecta rubra); the red circle identifies noxious and toxic cyanobacteria that can form large blooms in the lakes. Note Parvodinium pusillum (syn. Peridinium pusillum) 
bloom of Anabaena and Microcystis observed in May 2005 in Lake Cataouatche were not detected in the long-term monitoring (Turner et al., 2019). Microcystins were detected in April 2005 at $0.3-0.6 \mathrm{mg} \mathrm{l}^{-1}$ (protein phosphate inhibition assay; G. Boyer, SUNYSyracuse, unpublished data).

Delivery of Mississippi River water to adjacent waterways

When the DPD is open, river water is flushed south directly to Lake Cataouatche then south to Lake Salvador. Under high DPD discharge, e.g., in February 2006 (Fig. 2) during our experiments, the water volume of Lake Cataouatche could be completely replaced by Mississippi River water within 8 days, and Lake Salvador within 40 days. As diverted Mississippi River water travels into ambient water, the suspended particulate material falls out, and subsequent improvement in light conditions in the receiving Lake waters coupled with nutrient enrichment can lead to rapid phytoplankton biomass increases within days (Fig. 3). Other diversions of nutrient-rich waters, during flooding and for flood protection, coastal restoration activities, and wastewater treatment, may similarly affect ambient receiving waters (e.g., Dortch et al., 1999; Turner et al., 2004; Riekenberg et al., 2015; Turner, 2011; Bargu et al., 2019; Turner et al., 2019), or not (Bargu et al., 2019).

\section{Conclusion}

Our study provides evidence that there are consequences to the phytoplankton community from introducing Mississippi River water into the upper Barataria Basin lakes. The Chla yield was about 2.4-2.8 $\mu \mathrm{g}$ Chla $\mu \mathrm{mol} \mathrm{N} \mathrm{N}^{-1}$, which can be a useful indicator to evaluate changes in phytoplankton biomass in our study area and elsewhere. The multiple linear regression models derived from the experiments provided information on quantifying net phytoplankton production in relation to the input of DIN, SRP, and $\mathrm{Si}$, as predictor variables, which may be specific to the these lakes, and perhaps others. Application of our methodology would be useful in predictive models of responses to shifting water quality in numerous global situations as water resources change qualitatively and quantitatively and are increasingly manipulated by human activity.

Introducing Mississippi River water through the DPD, or other water diversions, can increase the phytoplankton biomass in the receiving lakes and cause increases in density of colonial and often toxic cyanobacteria. The molar ratios of DIN:ortho-P:Si in the Mississippi River are about 16:1:16 (Turner et al., 2007), and is not likely to change nutrient stoichiometry in the lakes in a matter of weeks because the phytoplankton uptake ratio of these three nutrients is close to the riverine ratios (Ren et al., 2009). The Chla concentration in the lakes in 2005-2006 was significantly higher (Table 2) than that in 1998-2002 (Ren et al., 2009). These high Chl $a$ concentrations and a dense bloom composed of Anabaena $\left(2.97 \times 10^{8}\right.$ cells $\left.1^{-1}\right)$ and Microcystis $\left(3.15 \times 10^{9}\right.$ cells $\left.1^{-1}\right)$ in Lake Cataouatche in May 2005, along with high concentrations of microcystins, could well be a result of the DPD opening.

Diverting Mississippi River water into local lakes and estuaries is proposed as an effective coastal restoration technique (CPRA, 2017), but the water quality in the diverted river may create problems in the ambient receiving waters or downstream, including documented changes in aquatic species quality and quantity (this study). The assumption of wetland restoration plans is that salinity will be reduced and that the introduced nutrients will fertilize emergent marsh growth. However, Turner (2011) demonstrated that excess nitrogen and phosphorus nutrient amendments to salt marshes, while they may stimulate above ground vegetation biomass, result in an increase in soil metabolism and lower root and rhizome biomass that will compromise soil strength and eventually contribute to marsh breakup. Further downstream into coastal waters, the $\mathrm{Si}: \mathrm{NO}_{3}-\mathrm{N}$ ratio in the Mississippi River, for example, shifted from 4:1 in the 1960s to 1:1 by the 1980s (Turner \& Rabalais, 1991), which may have affected the phytoplankton community composition in coastal waters (Turner et al., 1998). The diatoms, in particular, appear to have shifted toward smaller and more lightly silicified species (e.g., Skeletonema spp. and Cyclotella spp.; Rabalais et al., 1996; Dortch et al., 2001), which may further affect higher trophic level organisms in the water column and coastal water food webs (Turner et al., 1998). The more lightly silicified diatoms, included the potentially toxic diatom Pseudo-nitzschia spp., remains 
increased in sediment cores in coastal waters coincident with increased $\mathrm{N}$ loading from the Mississippi River and Si:N ratios < 1:1 (Parsons et al., 2002). Caution is needed, or potential effects considered, when implementing ecosystem recovery plans so that unintended consequences can be identified, weighed before decisions are made and, perhaps, mitigated.

Acknowledgements We thank Wendy Morrison Adam Sapp, Nazan Atilla, Lora Pride, Jim Lee, Kyle Reynolds, and David Wong for assistance during the experiments, and Charlie Milan for nutrient analyses. This work was supported by the National Oceanic and Atmospheric Administration, National Ocean Service, National Centers for Coastal Ocean Science, Center for Sponsored Coastal Ocean Research Awards No. NA16OP2671 to Louisiana Universities Marine Consortium (NNR) and No. NA16OP2670 to Louisiana State University (RET). This research was conducted under the NOAA, CSCOR, MULTISTRESS research program.

Open Access This article is licensed under a Creative Commons Attribution 4.0 International License, which permits use, sharing, adaptation, distribution and reproduction in any medium or format, as long as you give appropriate credit to the original author(s) and the source, provide a link to the Creative Commons licence, and indicate if changes were made. The images or other third party material in this article are included in the article's Creative Commons licence, unless indicated otherwise in a credit line to the material. If material is not included in the article's Creative Commons licence and your intended use is not permitted by statutory regulation or exceeds the permitted use, you will need to obtain permission directly from the copyright holder. To view a copy of this licence, visit http://creativecommons.org/licenses/by/4.0/.

\section{References}

Bargu, S., D. Justić, J. R. White, R. Lane, J. Day, H. Paerl \& R. Raynie, 2019. Mississippi River diversions and phytoplankton dynamics in deltaic Gulf of Mexico estuaries: a review. Estuarine, Coastal and Shelf Science 221: 39-52.

Brzezinski, M. A., 1985. The Si:C: N ratio of marine diatoms: Interspecific variability and the effect of some environmental variables. Journal of Phycology 21: 347-357.

Chorus, I. \& J. Bartram (eds), 1999. Toxic Cyanobacteria in Water. A Guide to Their Public Health Consequences, Monitoring and Management, E \& FN Spon (an imprint of Routledge), London.

Cloern, J. D., P. C. Abreu, J. Carstensen, L. Chauvaud, R. Elmgren, J. Grall, H. Greening, J. O. R. Johansson, M. Kahru, E. T. Sherwood, J. Xu \& K. Yin, 2016. Human activities and climate variability drive fast-paced change across the World's estuarine-coastal ecosystems. Global Change Biology 22: 513-529.
Conley, D. J., S. S. Kilham \& E. Theriot, 1989. Differences in silica content between marine and freshwater diatoms. Limnology and Oceanography 34: 205-213.

CPRA (Coastal Protection and Restoration Authority), 2017. Louisiana's Comprehensive Master Plan for a Sustainable Coast 2017. http://coastal.la.gov/our-plan/2017-coastalmaster-plan/.

Das, A., D. Justić, M. Inoue, A. Hoda, H. Huang \& D. Park, 2012. Impacts of Mississippi River diversions on salinity gradients in a deltaic Louisiana estuary: Ecological and management implications. Estuarine, Coastal and Shelf Science 111: 17-26.

Deegan, L. A., D. S. Johnson, R. S. Warren, B. J. Peterson, J. W. Fleeger, S. Fagherazzi \& W. M. Wollheim, 2012. Coastal eutrophication as a driver of salt marsh loss. Nature 490: 388-392.

Deininger, A., C. L. Faithfull, J. Karlsson, M. Klaus \& A.-K. Bergström, 2017. Pelagic food web response to whole lake $\mathrm{N}$ fertilization. Limnology and Oceanography 62: 1498-1511.

Dortch, Q., R. Robichaux, S. Pool, D. Milsted, G. Mire, N. N. Rabalais, T. M. Soniat, G. A. Fryxell, R. E. Turner \& M. L. Parsons, 1997. Abundance and vertical flux of Pseudonitzschia in the northern Gulf of Mexico. Marine Ecology Progress Series 146: 249-264.

Dortch, Q., M. L. Parson, N. N. Rabalais \& R. E. Turner, 1999. What is the threat of harmful algal blooms in Louisiana coastal waters? In Rozas, L. O., J. A. Nyman, C. E. Proffitt, N. N. Rabalais, D. J. Reed \& R. E. Turner (eds), Recent Research in Coastal Louisiana. Louisiana Sea Grant College Program, Baton Rouge, LA: 123-144.

Dortch, Q., N. N. Rabalais, R. E. Turner \& N. A. Qureshi, 2001. Impacts of changing $\mathrm{Si} / \mathrm{N}$ ratios and phytoplankton species composition. In Rabalais, N. N. \& R. E. Turner (eds), Coastal Hypoxia: Consequences for Living Resources and Ecosystems. Coastal and Estuarine Studies, Vol. 58. American Geophysical Union, Washington, DC: 37-48.

Edwards, V. R., P. Tett \& K. J. Jones, 2003. Changes in the yield of chlorophyll a from dissolved available inorganic nitrogen after an enrichment event-applications for predicting eutrophication in coastal waters. Continental Shelf Research 23: 1771-1785.

Egge, J. K. \& D. L. Aksnes, 1992. Silicate as regulating nutrient in phytoplankton competition. Marine Ecology Progress Series 83: 281-289.

Glibert, P. M., J. I. Allen, A. F. Bouwman, C. W. Brown, K. J. Flynn, A. J. Lewitus \& C. R. Madden, 2010. Modeling of HABs and eutrophication: status, advances and challenges. Journal of Marine Systems 83: 262-275.

Gowen, R. J., P. Tett \& K. J. Jones, 1992. Predicting marine eutrophication: the yield of chlorophyll from nitrogen in Scottish coastal waters. Marine Ecology Progress Series 85: 153-161.

Guildford, S. J. \& R. E. Hecky, 2000. Total nitrogen, total phosphorus, and nutrient limitation in lakes and oceans: is there a common relationship? Limnology and Oceanography 45: 1213-1223.

Hillebrand, H., C. D. Dürselen, D. Kirschtel, U. Pollingher \& T. Zohary, 1999. Biovolume calculation for pelagic and benthic microalgae. Journal of Phycology 35: 403-424. 
Hoyer, M. V., T. K. Frazer, S. K. Notestein \& D. E. Canfield Jr., 2002. Nutrient, chlorophyll, and water clarity relationships in Florida's nearshore coastal waters with comparisons to freshwater lakes. Canadian Journal of Fisheries and Aquatic Sciences 59: 1024-1031.

Lee, D. Y. \& G. Y. Rhee, 1999. Kinetics of growth and death in Anabaena flos-aquae (cyanobacteria) under light limitation and supersaturation. Journal of Phycology 35: 700-709.

Lohrenz, S. E., G. L. Fahnenstiel, D. G. Redalje, G. A. Lang, M. J. Dagg, T. E. Whitledge \& Q. Dortch, 1999. Nutrient, irradiance, and mixing as factors regulating primary production in coastal waters impacted by the Mississippi River plume. Continental Shelf Research 19: 1113-1141.

Madden, C. R., J. W. Day Jr. \& J. M. Randall, 1988. Freshwater and marine coupling in estuaries of the Mississippi River deltaic plain. Limnology and Oceanography 33: 982-1004.

Milligan, A. J. \& F. M. M. Morel, 2002. A proton buffering role for silica in diatoms. Science 297: 1848-1850.

Murrell, M. C., R. S. Stanley, E. M. Lores, G. T. DiDonato \& D. A. Flemer, 2002. Linkage between microzooplankton grazing and phytoplankton growth in a Gulf of Mexico estuary. Estuaries 25: 19-29.

Nielsen, S. L., K. Sand-Jensen, J. Borum \& O. Geertz-Hansen, 2002. Phytoplankton, nutrients, and transparency in Danish coastal waters. Estuaries 25: 930-937.

Paerl, H. W., J. T. Scott, M. J. McCarthy, S. E. Newell, W. S. Gardner, K. E. Havens, D. K. Hoffman, S. W. Wilhelm \& W. A. Wurtsbaugh, 2016. It takes two to tango: when and where dual nutrient ( $\mathrm{N}$ and $\mathrm{P}$ ) reductions are needed to protect lakes and downstream ecosystems. Environmental Science and Technology 50: 10805-10813.

Parsons, T. R., Y. Maita \& M. Lalli, 1984. A Manual of Chemical and Biological Methods for Seawater Analysis. Pergamon Press, New York.

Parsons, M. L., Q. Dortch \& R. E. Turner, 2002. Sedimentological evidence of an increase of Psuedo-nitzschia (Bacillariophyceae) abundance in response to coastal eutrophication. Limnology and Oceanography 47: 551-558.

Rabalais, N. N., 2004. Chapter 21: Eutrophication. In Robinson, A. R., J. McCarthy \& B. J. Rothschild (eds), The Global Coastal Ocean: Multiscale Interdisciplinary Processes, The Sea, Vol. 13. Harvard University Press, Cambridge: 819-865.

Rabalais, N. N., R. E. Turner, D. Justić, Q. Dortch, W. J. Wiseman Jr. \& B. K. Sen Gupta, 1996. Nutrient changes in the Mississippi River and system responses on the adjacent continental shelf. Estuaries 19: 386-407.

Raven, J. A., 1983. The transport and function of silicon in plants. Biological Review 58: 179-207.

Ren, L., N. N. Rabalais, R. E. Turner, W. Morrison \& W. Mendenhall, 2009. Nutrient limitation on phytoplankton growth in Upper Barataria Basin, Louisiana: microcosm bioassays. Estuaries and Coasts 32: 958-974.

Riekenberg, J., S. Bargu \& R. Twilley, 2015. Phytoplankton community shifts and harmful algae presence in a diversion influenced estuary. Estuaries and Coasts 38: 2213-2226.

Smith, V. H., 2006. Responses of estuarine and coastal marine phytoplankton to nitrogen and phosphorus enrichment. Limnology and Oceanography 51: 377-384.
Swenson, E. M., J. E. Cable, B. Fry, D. Justić, A. Das, G. Snedden \& C. Swarzenski, 2005. Estuarine flushing times influenced by freshwater diversions. In V. P. Singh \& Y. J. Xu (eds), Coastal Hydrology and Processes. Proceedings of the AIH 25th anniversary meeting and international conference "Challenges in coastal hydrology and water quality". Water Resources, Highlands Ranch: 403-413.

Sylvan, J. B., Q. Dortch, D. M. Nelson, A. F. M. Brown, W. Morrison \& J. W. Ammerman, 2006. Phosphorus limits phytoplankton growth on the Louisiana shelf during the period of hypoxia formation. Environmental Science and Technology 40: 7548-7553.

Teaumroong, N. \& S. Innok, 2002. Diversity of nitrogen-fixing cyanobacteria under various ecosystems of Thailand: 1 . Morphology, physiology and genetic diversity. World Journal of Microbiology and Biotechnology 18: 673-682.

Turner, R. E., 2011. Beneath the salt marsh canopy: loss of soil strength with increasing nutrient loads. Estuaries and Coasts 34: 1084-1093.

Turner, R. E. \& N. N. Rabalais, 1991. Changes in Mississippi River water quality this century. BioScience 41: 140-147.

Turner, R. E. \& N. N. Rabalais, 2013. Nitrogen and phosphorus phytoplankton growth limitation in the northern Gulf of Mexico. Aquatic Microbial Ecology 68: 159-169.

Turner, R. E., N. N. Rabalais \& Z.-N. Zhang, 1990. Phytoplankton biomass, production and growth limitations on the Huanghe (Yellow River) continental shelf. Continental Shelf Research 10: 545-571.

Turner, R. E., N. Qureshi, N. N. Rabalais, Q. Dortch, D. Justić, R. Shaw \& J. Cope, 1998. Fluctuating silicate:nitrate ratios and coastal plankton food webs. Proceedings of National Academy of Sciences (USA) 95: 13048-13051.

Turner, R. E., Q. Dortch \& N. N. Rabalais, 2004. Inorganic nitrogen transformations at high loading rates in an oligohaline estuary. Biogeochemistry 68: 411-423.

Turner, R. E., N. N. Rabalais, R. B. Alexander, G. McIsaac \& R. W. Howarth, 2007. Characterization of nutrient and organic carbon and sediment loads and concentrations from the Mississippi River into the northern Gulf of Mexico. Estuaries and Coasts 30: 773-790.

Turner, R. E., N. N. Rabalais \& D. Justić, 2008. Gulf of Mexico hypoxia: alternate states and a legacy. Environmental Science and Technology 42: 2323-2327.

Turner, R. E., E. M. Swenson, C. Milan \& J. M. Lee, 2019. Spatial variations in Chlorophyll $a, \mathrm{C}, \mathrm{N}$, and $\mathrm{P}$ in a Louisiana estuary from 1994 to 2016. Hydrobiologia 834: 131-144.

Walsby, A. E., P. K. Hayes, R. Boje \& L. J. Stal, 1997. The selective advantage of buoyancy provided by gas vesicles for planktonic cyanobacteria in the Baltic Sea. The New Phytologist 136: 407-417.

Wong, W. H., N. N. Rabalais \& R. E. Turner, 2016. Size-dependent top-down control on phytoplankton growth by microzooplankton in eutrophic lakes. Hydrobiologia 763: 97-108.

Publisher's Note Springer Nature remains neutral with regard to jurisdictional claims in published maps and institutional affiliations. 